revista ANTHROPOLÓGICAS

Ano 23, 30(1): 5-37, 2019

\title{
O Mal e os Amores Difíceis: tecidos relacionais habitados por homens condenados por estupro de vulnerável e mulheres a eles vinculadas
}

\author{
Everton Rangel $^{\mathrm{a}}$
}

\begin{abstract}
Neste artigo, resultado de uma etnografia que tem como interlocutores homens condenados por terem cometido estupro de vulnerável e pessoas a eles vinculadas afetivamente, descreverei os efeitos das sentenças condenatórias em tecidos relacionais, dando especial atenção ao problema do mal, causador de sofrimento, e às formas de engajamento com o outro que perpassam, sobretudo, mas não exclusivamente, a prática do amor. $\mathrm{O}$ trabalho - a um só tempo afetivo, burocrático, moral e narrativo - ao qual os meus interlocutores se devotam sugere a necessidade de produção de relações em que os sentenciados possam habitar como homens injustiçados, vinculados a pessoas que os amam em atos e junto a eles combatem a substância do mal. A minha aposta mais abrangente é a de que devemos entender esse trabalho como um atividade relacional de cunho ético. Busco, ao fim, descortinar uma série de nexos entre emoções, moralidade, Estado e gênero.

Estupro, Amor, Moralidade, Mal, Estado.
\end{abstract}

\section{'Fazer falar' as relações}

Dentre os homens que conheci, excluídos aqueles com transtorno mental, apenas um admitiu ter cometido estupro. Esse dado revela o empenho frequente dos meus interlocutores em se afastar da mons-

a Doutorando no Programa de Pós-Graduação em Antropologia Social (UFRJ-MN). Membro do NuSEX (Núcleo de Estudos em Corpos, Gêneros e Sexualidade) e do NESCOM (Núcleo de Estudos das Sociedades Complexas). Email: era.rangel@gmail.com. 
truosidade associada aos que cometeram crimes sexuais. Embora explore neste artigo $^{1}$ apenas o discurso de sentenciados pelo estupro de crianças e adolescentes, cabe sinalizar um argumento de Machado (1998) relevante à discussão que proponho. A autora defende que o estigma de estuprador era vivenciado pelos seus interlocutores, acusados de estuprarem mulheres, como um aspecto mais crítico do que a discussão sobre a violência sexual. Nesse sentido, é a ideia de estuprador, e não a de estupro, que parece não ser da ordem do cotidiano. Sente-se vergonha do estigma, mas não exatamente da relação sexual criminosa, a tal ponto que a violência pode assumir qualidade trivial nos relatos masculinos. Raras as exceções, os meus interlocutores usualmente sobressaltavam a impossibilidade de serem empurrados para fora do terreno da humanidade como monstros (Lowenkron 2015), mas não chegavam a banalizar explicitamente a violência sexual. Ao contrário, o comum era que negassem autoria dos crimes a eles imputados e reafirmassem a atrocidade do estupro de vulnerável, afinal, não se pode atribuir desejos, nem mesmo qualquer consentimento, à menores de idade sem que o autor dessa declaração seja instantaneamente maculado.

Enquanto alguns dos entrevistados de Machado culpabilizavam as vítimas, como se elas dissessem 'não' querendo dizer 'sim', nas conversas com os homens que conheci pude perceber que a sacralização da infância costumava operar como um limite moral contundente, algo que deveria ser repetido com ar de concordância, ainda que o objetivo principal do discurso fosse a limpeza moral ou o afastamento da máscara do estuprador.

Menos do que contestar a realidade desse esforço, a minha intenção é a de objetivá-lo, refletindo, por um lado, sobre o quadro estabilizado de relações que os sentenciados e as pessoas a eles ligadas afetivamente buscavam compor narrando no presente os meandros da injustiça da qual foram alvos no passado e, por outro lado, sobre as ações daqueles que crêem continuamente nesse discurso moral. $\mathrm{O}$ trabalho ao qual os meus interlocutores se dedicavam sugere o quão 
indispensável era a produção, tanto narrativa quanto 'concreta', de tecidos relacionais onde os próprios acusados podiam habitar como homens injustiçados vinculados a pessoas que os amavam em atos e junto a eles clamavam por justiça. Ao descrever o habitar em tecidos relacionais afetados por acusações vividas como falsas, porém legitimadas pelo Estado como verdade jurídica, busco responder três perguntas principais: (1) por que a moralidade do mal era vital à estabilização narrativa de relações?; (2) qual vínculo existe entre empreendedores morais responsáveis pela acusação de estupro e a Justiça em maiúsculo?; (3) como amores construíam a realidade da injustiça?. A minha aposta mais abrangente é a de que a possibilidade dos homens sentenciados viverem no mundo que compartilhamos como homens honestos, e não como monstros, depende de uma atividade relacional de cunho ético manifesta em atos morais, afetivos e/ou discursivos capazes de cruzar temporalidades.

À cada homem condenado ou 'familiar' que conhecia, mais claro ficava que certos traços congelavam-se nas narrativas que descaracterizavam estupros: sempre havia ao menos um(a) empreendedor(a) moral responsável pela acusação, mulheres majoritariamente, e elas(es) eram costumeiramente percebidas(os) de maneira bastante negativa: invejosas(os); loucas(os); ciumentas(os); vingativas(os); manipuladoras(es); e etc. "Ela queria ficar com o meu carro", ouvi mais de uma vez. Nessa frase, relativa a um processo lento de separação, a esposa que aparece implicitamente foi descrita enquanto interesseira, como se a ganância dela fosse uma razão suficiente em uma dada circunstância relacional. Havia outras: "ela queria ficar com as crianças"; "não aceitou a traição"; "não tem limites"; "queria me ferrar de qualquer jeito"; e etc. Os homens podiam também sentirem-se responsáveis indiretamente pela acusação descabida: "eu traí muito"; "o relacionamento não era legal"; "estava metido com jogo"; "bati nela"; "a bebida era o problema"; "caímos na porrada"; e etc. Estou menos interessado no amplo repertório de porquês do que na compreensão dos aspectos constantes: mulheres más, homens bons - ou nem tão 
bons assim - relacionamentos afetivos e/ou profissionais complicados e acusações infundadas. Ao longo deste artigo, buscarei demonstrar como a moralidade do mal está associada às relações de gênero, mais frequentemente ao feminino no discurso dos sentenciados e pessoas a eles ligadas. Para compreender essa produção narrativa, inspiro-me na proposição de Austin (1962): a linguagem não é meramente referencial, simples constatação do mundo, pois, ao contrário, os enunciados operam como atos, produzindo aquilo que nomeiam - inclusive o mal manifesto através da plêiade de características negativas acionáveis. Embora saiba que toda narrativa estabiliza-se através da repetição dos atos de fala e das alterações de sentido, acentuarei o quadro congelado de relações que os meus(minhas) interlocutores(as) objetivavam fomentar porque desse congelamento dependia a própria substancialização do mal em empreendedores(as) morais contrapostos(as) aos benfeitores.

Certamente, podia-se também afastar-se do estigma através da ocultação do mesmo às pessoas que desconheciam a sentença condenatória. Atenho-me aqui aos efeitos da desconfiança que nutri quanto a um interlocutor em razão da prática de ocultação por ele promovida e direcionada a mim e a sua namorada. Pode-se dizer que evito situar-me no texto etnográfico unicamente na posição de agente replicador de discursos de verdade centrados na injustiça. Busco alternar as posições a partir das quais lidei com pessoas, narrativas e relações, de modo a complexificar o que se pode apreender dos atos de fala e das práticas de ocultação. Como um antropólogo pode fazer fracassar uma narrativa que se pretendeu bem sucedida? Quais são as condições de felicidade dos atos de fala? Ao me preocupar com o congelamento da narrativa da injustiça e com as condutas decorrentes da crença nessa narrativa ou decorrentes da desconfiança em torno dela, volto-me à análise da moralidade dos comportamentos. Considero que é preciso atentar para o modo como os sujeitos reconhecem a si mesmos não simplesmente como agentes, mas, sobretudo, como sujeitos de uma dada ação ético-moral (Foucault 2006). Não basta 
dizer que tanto a confiança quanto a desconfiança são sentimentos morais cultivados em relação a alguém, nem mesmo que a tomada de posição moral deriva desses sentimentos (Lutz 1998)², pois é preciso reconhecer também como as pessoas com eles se relacionam, como os sustentam, como os transformam em atos, a quem os devotam, por quê e em quais circunstâncias, mantendo a análise em um plano eminentemente ordinário. Na medida em que estou fazendo alusão às disposições éticas cultivadas na interação cotidiana com homens que, se para mim eram interlocutores, para outros eram pais, maridos, namorados, companheiros, filhos e afins, não posso deixar de demarcar que, conforme variavam as relações, bem como a proximidade e a densidade dos laços, variavam também as disposições para ação.

Longe de afirmar que o parentesco define regras de comportamento e sentimento a serem seguidas de modo automático, como se estivesse defendendo a obrigatoriedade do sentimento de confiança transformado por uma esposa em ato de amor devotado a seu marido, quero sugerir que um enorme trabalho de automodelação pode informar os atos e perpassar o cultivo das disposições morais em relação a alguém. Foucault diria que não há "necessidade de algo como um texto que faça a lei [do parentesco, no caso], mas de uma tcheme ou de uma 'prática', de um savoir-faire que, levando em conta os princípios gerais, guie a ação no seu próprio momento, de acordo com o contexto e em função de seus próprios fins" (Foucault 1998:27). Com essas proposições o autor questiona a relevância da ênfase kantiana na ética como conduta passível de generalização e reclama a análise dos modos de ser e se portar, além das justificações da conduta. $\mathrm{O}$ argumento é o de que a ética excede a simples perseguição de regras sancionadas ou indivíduos voluntaristas, já que relativa às práticas cujas cores precisas vinculam-se ao largo a repertórios de pensamento e ação historicamente tornados possíveis. $\mathrm{O}$ trabalho de auto-modelação, sempre alinhado a um outro, implícito ou explícito, revela-se assim como prática ética a ser analisada em acordo aos contextos. De uma perspectiva antropológica isso é particularmente interessante, pois comporta um 
mandamento etnográfico: a atenção é dirigida aos engajamentos ordinários de uns com os outros e de si consigo mesmo, sem que seja desconsiderada a existência de relações de sujeição que habilitam, mas não determinam, os atos. Para dar carnatura a essa colocação, pode-se pensar que a sentença condenatória sujeita não apenas aquele que foi preso, mas também as pessoas que a ele se irmanam. Desse ângulo, a injustiça é um efeito da condenação: um discurso moral dos perderam para a Justiça, isto é, não puderam fazer das suas verdades a verdade jurídica, mas persistiram trazendo ao mundo atos de amor e suscitando desconfianças.

Com quais valores, símbolos, proclamações e/ou 'regras' de conduta mais se preocupa? Como é realizado o balanço entre os compromissos com os quais se identifica e com os quais não? Volto as perguntas de Lambek (2015) ao material etnográfico que disponho e, nesse movimento, descrevo a distinção entre confiança e desconfiança a partir da diferença entre que importava a mim e o que importava aos meus interlocutores nos momentos em que interagimos. Enquanto estava preocupado em forjar maneiras de não repercutir ingenuamente discursos de verdade de homens sentenciados por crimes sexuais, as pessoas que conheci pareciam interessadas em afastar o estigma e construir narrativas críveis. Se do ponto de vista de um(a) deles(delas), o meu sentimento de desconfiança é questionável; do ponto de vista que nutri por certo tempo em campo, desconfiar era uma modalidade de ação eticamente orientada no sentido do que entendia serem causas feministas - refiro-me, por exemplo, à luta para que a desconfiança deixe de recair sobre as vítimas e deixe de culminar no descrédito da denúncia de estupro. Como me debruçarei sobre a discussão da desconfiança, basta evidenciar por hora que não há uma substância per se do que seja a ação ética, pois não é possível defini-la ou adjetivá-la sem que se saiba o que importa a cada um em cada contexto ou sem que se descreva como disputas de sentido de mundo podem informar, temporariamente ou não, a condução da pesquisa acadêmica. A preocupação de Lambek (2015) com a 'tonalidade da vida', ao mesmo 
tempo em que insinua que a reflexão antropológica contemporânea em torno da ética deriva de uma ênfase na prática e culmina em abordagens centradas na experiência, está aliada à compreensão da ética não como um domínio estanque da realidade, e sim enquanto qualidade imanente às ações - melhor compreendida como advérbio ou adjetivo do que como substantivo ('a ética').

Quando direciono a análise ao que importava aos meus interlocutores, bem como ao que importou a mim em momentos precisos, estou pensando também que os atos éticos têm tanto a ver com automodelações, ponderações ou exercícios reflexivos, quanto com disposições internalizadas, hábitos sedimentados ou respostas a chamados de terceiros que nos invadem sem muita mediação consciente. A questão não é, portanto, a de definir fronteiras estáveis entre o que é refletido ou não em um comportamento, mas entender precisamente como os discursos nos pertencem, as ações nos importam e ambos emanam de/em relações. Porque a tendência é a de associarmos a prática ética às situações limites, aquelas que implicam um processo lento e meticuloso de julgamento moral, é preciso "complexificar nossa imagem do hábito e mostrar como uma disposição ética é cultivada no âmbito do ordinário como uma atenção intensificada no interior do hábito, em vez de fora dele" (Das 2012:345). O leitor perceberá que me desloco de uma ênfase a outra, embaralhando-as e atribuindo relevância aos momentos reflexivos intensivos e aos gestos de devoção fundados no cultivo habitual de disposições. A ideia de contínuo mobilizada por Lambek (2015) é uma boa alegoria, se entendermos que não se trata somente de identificar como se passa de um ponto ao outro, nem somente de graus, pois nas relações o refletido e o irrefletido se cruzam, esbarram, separam, colidem e fundem de múltiplas maneiras.

Pablo e Altair, dada a dimensão monstruosa do crime que empreendedores morais afirmaram que eles cometeram e procedimentos judiciais corroboraram, não mais podem ser plenamente os homens que eram, mas a eles cabe uma vida digna no que depende especialmente 
daquelas que os amam em atos. Ao voltar-me à vida afetada pelo mal e cuidada por intermédio dos gestos de amor, como os de Roberta e Helena, distancio-me dos estudos que, na antropologia, analisam o discurso de homens sentenciados por estupro em aproximação aos escritos da psicanálise. Faço esse movimento na esperança de retirar rendimentos analíticos do que pude escutar, mas, sobretudo, das relações que os meus interlocutores e minhas interlocutoras estabilizavam em narrativas sobre o passado e dos tecidos relacionais nos quais eles(elas) habitavam durante o curso da pesquisa. A injustiça é, nesse sentido, uma vocalização que permite que as pessoas afetivamente vinculadas reconheçam a si mesmas, ajam umas em relação às outras e atribuam conjuntamente sentido negativo às práticas daqueles que elas substancializam como malfeitores. Se deixo de perseguir, neste artigo, o investimento nas teorias do inconsciente, é porque o desafio analítico ao qual me devoto é o de 'fazer falar as relações', expressão cunhada por Fabiana Andrade (2018), em um plano mais fenomenológico. Quero assim dizer não somente que preocupo-me com a ordem do acontecimento, como também que escutar aos meus(minhas) interlocutores(as) implicava ser envolvido e levado pelas relações. Nelas trafegando, passei a perguntar-me sobre a extensão do mundo em que os homens sentenciados e aqueles(as) que os(as) amavam habitavam. Passei a indagar como as relações transportavam discursos de verdade, para quais direções tais discursos seguiam e até que ponto se sustentavam nas relações.

\section{Os sentidos e os efeitos da desconfiança}

Pablo cumpria pena no regime semi-aberto quando nos conhecemos no gabinete da defensora pública Fabiana. Oficialmente, ele podia trabalhar de segunda à sexta em horário comercial e retornar à unidade carcerária no final de cada expediente. Para ir à Defensoria reclamar benefícios, Pablo recebia dispensa temporária do serviço e a ele retornava munido de uma ressalva - documento que atestava o período que lá permaneceu. A ressalva possibilitava também que, 
ao tempo dedicado à assistência jurídica, fosse somado o tempo despendido com a pesquisa, gerando um período único controlado pela defensora Fabiana. É acertado dizer que, através dos procedimentos de regulação do deslocamento de Pablo pela cidade, pude trafegar pelo tecido relacional desse homem. Ele dizia que não podia ter sido acusado de ter cometido estupro, já que tinha 'namorado' uma jovem, Marlene, de cerca de dezesseis anos. Diferente do que geralmente ocorria, não pude gravar o que ele me contou. Estava claro que o meu interlocutor desconfiava das minhas intenções e buscava controlar o que eu poderia vir a dizer sobre o modo como ele discursivamente colocava em tensão a violência sexual e as relações afetivas. Em seu relato, Marlene não podia ser tratada como vulnerável devido a sua idade e às relações em que estava inserida.

Pablo conheceu Marlene numa festa organizada pela Prefeitura de um município adjacente à região metropolitana do Rio de Janeiro em comemoração ao dia do trabalhador. Tanto ele quanto a mãe de Marlene trabalhavam na prefeitura. Pablo ocupava um cargo comissionado de assessoria, ela era uma das copeiras. Dentre os dois, situava-se a disparidade de cunho salarial e também a de prestígio. $\mathrm{O}$ primeiro beijo trocado com a jovem, publicamente na festa, teria resultado em passeios que reuniam toda a família. Por vezes, Marlene, que tinha um filho de cerca de dois anos, o levava para os encontros. O relacionamento seguiu até o momento em que Pablo decide reatar o casamento com a sua ex-mulher. A mãe de Marlene teria então ficado enfurecida porque via em Pablo um provedor capaz de sustentar a sua filha e o seu neto. A recusa dele em permanecer sendo tal homem resultou, a seu ver, na denúncia que sua então sogra fez à polícia. $\mathrm{O}$ estupro de Marlene seria elaboração de sua mãe - uma pessoa ardilosa, cujo gesto de vingança vela o interesse financeiro e simbólico. Desse ângulo, Marlene existe como objeto de troca constitutivo da relação entre a sua mãe e o seu namorado. Se a mãe autoriza a relação proibida com base em demandas, Pablo desfruta do prazer propiciado por Marlene pagando jantares, dando presentes ou simplesmente 'ajudando'. 
A filha/namorada aparece como objeto ativo de troca. Ela é descrita como provocadora, figura semelhante a da novinha (Fernandes 2018) capaz de conhecer os termos da relação na qual se engaja e de tirar vantagem do proibido sem ser vingativa como a sua mãe. À figura do provedor vincula-se a figura da mãe má que agencia a própria filha num trânsito relacional que não à toa é retratado em aproximação à prostituição.

Posta nesses termos, a acusação de estupro emerge maculada pela cafetina que a mãe de Marlene é no interior do tecido relacional, narrativamente congelado pelo meu interlocutor em menos de uma hora de conversa. Quando percebeu que eu havia compreendido o sentido da dinâmica relacional que narrava, Pablo me deu seu número de telefone, bem como passei o meu para ele. Combinamos que seguiríamos conversando na próxima vez que ele fosse ao atendimento e deixamos em aberto a possibilidade de conhecer a sua família. Estranhei não mais tê-lo visto, porque era comum os assistidos retornarem semanalmente à Defensoria. Meses depois, um tanto ingenuamente, telefonei para ele durante a tarde - período em que estaria trabalhando no almoxarifado de uma repartição pública. Como ninguém atendeu, desisti. Horas depois, recebo uma ligação do número que Pablo havia me dado. Atendi, me identifiquei e a pessoa do outro lado da linha disse ser a namorada dele. Roberta tinha ficado com o celular devido a um incidente. Pablo havia sido transferido para um presídio em Bangu, o que significava que ele não mais sairia para trabalhar e nem mesmo seria atendido pela defensora Fabiana.

Roberta estava desesperada porque alguém tinha denunciado que Pablo, aos sábados, não trabalhava. Ele passava o dia na casa dela. "Por que isso está acontecendo justo agora?", Roberta perguntou a mim como se não esperasse uma resposta. $\bigcirc$ que ela queria saber era o que aconteceria com seu namorado e, sobretudo, como poderia visitá -lo. A sua voz estava trêmula quando começou a agradecer o fato de eu ter me disposto a buscar informações jurídicas, ainda que estranhasse a situação de trabalho relatada por ela. Após dizer que Deus tinha me 
colocado em seu caminho, Roberta me contou que conheceu Pablo em um site de relacionamentos e que, no início, teve dificuldade para entender a 'situação dele'. Ela não mencionava o crime que eu imaginava estar em questão, estupro, nem mesmo descrevia circunstâncias que pudessem me fazer entrevê-lo. Trava-se da 'situação dele'. Fazia meses que estavam se relacionando. "Deus não escreve por linhas tortas", disse. Era amor o que sentia e só o amor pode a tudo suportar. Roberta finalizou a ligação recitando a Bíblia, trechos de 1 Coríntios 13, e cantando a música Monte Castelo, de Renato Russo, inspirada no mesmo versículo bíblico.

Ainda que eu falasse

A língua dos homens

E falasse a língua dos anjos

Sem amor eu nada seria

É só o amor! É só o amor

Que conhece o que é verdade

O amor é bom, não quer o mal

(Monte Castelo, Renato Russo)

Tal como prometi, retornei a ligação. Roberta estava na igreja. Seu filho, Junior, me orientou a ligar para o celular dela. Quando conversamos, Roberta frisou que Junior também sentia falta de Pablo. A sua esperança era a de eu conseguisse ajudá-la a fazer uma carteirinha de visitante para que, mesmo sem Junior, pudesse entrar no Complexo de Bangu e então abraçar o seu namorado. A família de Pablo não a ajudava a conseguir o documento por causa da 'situação dele': a irmã o detestava; a mãe fazia o mínimo possível; a ex-mulher, Roberta sequer conhecia; os filhos do primeiro casamento havia visto apenas através das fotografias que ele exibia em momentos saudosos. Àquela altura, a expressão 'situação dele' operava como uma omissão de uma informação que parecia importante manter não esclarecida. Seguimos conversando sobre a família de Pablo até o momento em que Roberta muito rapidamente disse: "a família não supera a situação do menino". "Que menino?", pergunto. Ela, tergiversando, como se buscasse as palavras que lhe fugiam, menciona um homicídio. Foi atendo-me 
ao que Roberta me contou, de forma breve e sem detalhes, que deixei de contar a ela o que Pablo, meses antes, tinha me dito sobre o crime pelo qual teria sido injustamente condenado. A expressão 'situação dele' seguia, contudo, me intrigando. Aquele que eu conhecia Roberta nunca namorou. O homicídio que o amor contornava não existia para mim como declaração de Pablo. Do meu ângulo, 'a morte do menino' era uma mentira contada pelo meu interlocutor a sua namorada. Mas, vendo do ângulo de Roberta, era a narrativa de injustiça que eu conhecia que sequer tinha sentido. Existiriam ainda informações no processo de conhecimento que eu desconhecia? Existiriam dois processos, um de homicídio e outro de estupro?

Peço um modelo de petição de desarquivamento à Fabiana para fazer o requerimento do processo de conhecimento de Pablo, protocolo o pedido na ficha dele e coloco o documento em cima da pilha de papéis que precisavam ser averiguados, corrigidos e assinados para então serem expedidos. Estava claro que eu não poderia transmitir aos assistidos e aos seus familiares informações contidas em processos de conhecimento e reguladas pela confidencialidade jurídica. $\mathrm{O}$ combinado que fiz com a defensora era o de que a leitura desses documentos orientaria a análise antropológica e também a prática jurídica no sentido dos propósitos que lhe eram inerentes no gabinete de Fabiana. Esperava-se que o desarquivamento de qualquer processo alimentasse a instrução da defensora e sua equipe em uma linguagem a ser traduzida em ações aptas a beneficiar aos assistidos na fase de execução penal. Se uma petição de desarquivamento pode terminar realizando-se como materialização da desconfiança que cultivei em relação a Pablo, a decisão de não mais contatar Roberta é um gesto informado, por um lado, pela lógica da confidencialidade jurídica que não permitia que eu contasse a ela sobre o que existe nos autos e, por outro lado, pela demanda ética de não intervir em prejuízo de nenhum interlocutor, ou assistido da defensora Fabiana, que tivesse aceitado participar da pesquisa. Parece indispensável, antes de apresentar o que contam os documentos, perscrutar melhor os sentidos e os efeitos da desconfian- 
ça, além da relação desse sentimento com o da confiança.

Matthew Carey (2017) argumenta que a ênfase sociológica, simmeliana para ser mais preciso, na confiança como sustentáculo indispensável à formação da sociedade vincula-se à percepção segundo a qual a desconfiança é socialmente ácida: se a primeira solda os laços, a segunda os ameaça. $\mathrm{O}$ próprio ato de confiar, no entanto, pode ser desconfortável, azedo, já que riscos são assumidos por quem se fia na expectativa de que os atos de alguém se configurem como o esperado. Nesse sentido, a confiança tanto revela a dependência entre as pessoas quanto implica alguma aceitação do controle relativo, por vezes diminuto, que se pode exercer em relação ao comportamento do outro. $\mathrm{O}$ autor reconhece a vitalidade da análise do risco como aspecto inerente ao ato de confiar, refuta a ideia de que onde há confiança não há desconfiança e questiona qual é o efeito da hipótese da confiança como cimento do social sobre a análise da desconfiança. Uma das conclusões de Carey é que:

"The hypotheses of trust and mistrust are not mutually exclusive ways of viewing others, but are to an extent constitutive of one another. Each implies its shadow: where people assume that others can be known and so trusted, they are also aware that sometimes this does not hold; and where they assume that others are largely unknowable, they are also aware that some are less unknowable than others" (Carey 2017:10).

Na etnografia de Carey, é claro o esforço em demonstrar que laços sociais podem derivar também da desconfiança. Defende-se que no Alto Altas, Marrocos, a desconfiança é uma prática generalizada que, ao invés de indicar quebras na socialidade, faz a sociedade de maneira específica: amigos que desconfiam sistematicamente uns dos outros podem mais rapidamente perdoar danos sofridos, isto é, uma pessoa 'x' pode deixar de lado o efeito da desconfiança de 'y' sobre si porque ela conhece a potência de sua própria atitude de suspeição. Certa tolerância em relação ao outro seria provocada através da desconfiança. Embora não seja o meu interesse adentrar nas especificidades do material de Carey, como o faz Maya Mayblin (2019), devo dizer que 
a autora argumenta que em Mistrust: an ethnographic theory deixa-se de lado a compreensão do modo como a desconfiança participa do processo de construção das instituições. O patriarcado é pensado pela autora como uma instituição caracterizada pela suspeição entre mulheres e homens, presente em Alto Altas e não analisada no livro em questão. Por um lado, isso aconteceria porque a visão estreita de Carey das instituições como composições formais, duráveis e coercitivas, o faz argumentar que a própria ideia de instituição é pouco operativa no Alto Altas; ali, imperaria um anarquismo sustentado pela generalização da desconfiança. Por outro lado, o patriarcado não seria analisado porque a desconsideração dos estudos voltados ao gênero impediria a identificação pelo autor da relevância da relação entre honra e vergonha em seu material etnográfico, bem como dificultaria a compreensão de que, ainda que tal relação possa culminar em tolerância, não há porque recusar que violência e morte são também efeitos possíveis do patriarcado. De acordo com Mayblin (2019: n.p.):

"Patriarchy is a key institution in 'honour and shame' contexts, as it encompasses other institutions such as the lineage, marriage and perduring patterns related to property and inheritance. In my own field-site, where patriarchy structured life at various levels - not all of which would be immediately or obviously apparent to an ethnographer - mistrust was fairly pervasive, particularly between men and women. However, that mistrust was buffered by an under-thecounter sort of honour-shame complex which, far from generating tolerance in the face of betrayal, prescribed violent retaliation and sometimes even death" (Mayblin 2019: n.p.).

O primeiro ponto a ser assinalado em relação ao caso de Pablo é o de que a combinação entre a desconfiança que nutri e a que ele sentiu não resultou em tolerância, mas gerou efeitos (busca por documentos e impossibilidade de gravar falas) que deram vida à configuração precisa que a nossa relação assumiu. Carey parece, desse ângulo, correto em dizer que a desconfiança está presente na formação dos laços, não sendo, portanto, apenas corrosiva. Já a preocupação 
de Maya Mayblin com a relação entre gênero e desconfiança é pertinente para fazer ver que desconfiando de Pablo buscava distinguir modelos de masculinidade, reservando ao meu interlocutor uma performance mais próxima ao que autora poderia chamar de patriarcal em função das características da narrativa de injustiça dele. Pensando na relação entre Roberta e Pablo, pode-se dizer que não é exatamente a desconfiança que faz a tolerância, mas sim o amor que tudo pode. A essa altura, deve estar claro que tanto a confiança quanto a desconfiança estão, a meu ver, intricadas às relações de gênero, mas talvez ainda esteja pouco evidente que, embora entenda a importância da aproximação do par honra-vergonha ao patriarcado na argumentação de Mayblin, opto por não restringir a compreensão das relações de gênero ao modelo analítico do patriarcado. Faço esse movimento não apenas para afastar-me da possibilidade do patriarcado revelar-se como unidade monolítica de poder $^{3}$ (Piscitelli 2002), mas também, e, sobretudo, para agregar dinamismo às múltiplas relações entre masculinidades e feminilidades no que tange os sentidos da confiança e da desconfiança.

Quando Roberta confia em Pablo, ela está fazendo a si partir de uma versão do feminino disposto a amar, a tolerar e/ou a cuidar; quando desconfio dele, estou fazendo a mim a partir de um apelo a uma masculinidade que se quer alinhada aos discursos igualitários; quando Pablo desconfia de mim, faz a si a partir da figura do provedor traído por uma mãe vingativa. São essas diferenças valorativas que fazem com que opte por pensar as relações de gênero menos como instituição patriarcal, cujos contornos são a priori conhecidos, e mais como performatividade ${ }^{4}$ - grosso modo, conjunto de atos reiterados que tanto pode sedimentar as relações de gênero de maneira hierárquica e/ou violenta, quanto pode desestabilizá-las (Butler 2006). Pensar o gênero como performatividade possibilita a intensificação da atenção voltada ao sentido e aos efeitos dos atos, sejam aqueles despendidos pelos(as) meus interlocutores(as), sejam aqueles efetuados por mim. Ao dar-me conta, ainda em campo, que o sentimento 
de desconfiança que alimentei fazia de Pablo um homem que não se resume àquele que ele fez questão de narrar a mim, nem mesmo ao namorado que Roberta conheceu, entendi que os meus atos faziam as relações de gênero circularem no meu material de maneira específica. Pablo tornou-se o efeito de uma composição discursiva e relacional que difere do modo como pude compor Altair, figura sobre a qual falarei adiante, porque a esse último fui me aproximando em um movimento de afastamento relativo das práticas administrativas que facultavam a aparição da verdade jurídica. Pode-se dizer que a interação, baseada na desconfiança, e a interação, mais focada no que as pessoas colocavam à mostra, distinguem-se enquanto modalidades de sociabilidade que permitem ver facetas particulares dos sentimentos e atos morais que fazem o gênero e os vínculos interpessoais em contextos precisos.

Desfecho: Roberta seguiu em sua casa amando o seu namorado, mas sem poder visitá-lo em Bangu; Pablo passou a responder pela infração cometida durante a execução penal; e eu segui esperando o desarquivamento do processo de conhecimento dele. Quando finalmente o mesmo foi remetido, folheando-o percebi que as personagens que compunham a injustiça narrada por Pablo não existiam ali. Nenhum sinal de Marlene ou sua mãe. Nos autos, o estupro que existia era uma menina de dois anos. Esse é um caso crítico porque reúne à narrativa de injustiça elementos não convencionais: uma vítima diferente daquela anunciada a mim, o homicídio de um jovem e uma mulher religiosa apaixonada. A história de Pablo, ao evidenciar a capacidade mais ou menos eficaz que os sujeitos têm de modular a verdade sedimentada pela administração estatal, explicita a força da máscara monstruosa posicionada sobre a face dele. Pablo prefere ser um assassino a ser um estuprador. Mas ele prefere, sobretudo, não ter estuprado a criança que existe nas peças processuais. São em situações como essa que impera a sacralização da infância como um limite moral ou um dispositivo capaz de regular o dizível a um antropólogo e a uma mulher com a qual uma relação amorosa foi nutrida. 


\section{De Helena para Altair: a forma burocrática do amor}

Se você me dissesse que eu não poderia lutar contra os obstáculos que me fizeram ficar longe de você, eu teria tentado do mesmo jeito... Na batalha dura que vivemos, eu não parei de pensar você um minuto sequer... A vida não se trata dos obstáculos que pulamos, e sim daqueles que tropeçamos, caímos, sentimos dor, aprendemos, levantamos e simplesmente pegamos outro caminho. Fui seguindo o amor, atravessando todos os obstáculos, e correndo todos os riscos pelo simples prazer de amar você... Fazer amor é caminhar juntos, é crescer juntos... E amar é isso. É auxiliar o outro a saltar obstáculo, mesmo quando suas próprias forças estão extintas. Acredito que o amor anda junto à fé, pois ele vê no impossível, o possível acontecer. Amo você @[Altair] (Postagem feita por Helena no facebook no dia dos namorados - 12/06/2018).

Trafegar nas relações onde a narrativa de injustiça floresce é uma tarefa que implica gestos menos comprometidos do que aqueles atuadas por quem de fato habita nessas relações. $\mathrm{O}$ amor que Helena sentia por Altair está marcado em uma série de atos continuados dela em prol dele. Depois da prisão de seu marido, motivada por acusações de estupro de vulnerável promovidas pelas mães das crianças que estudavam na creche que o casal possuía e geria, Helena investiu na injustiça especializando-se na lida com a burocracia. Porque acreditava na inocência de seu marido, ela devotou anos de sua vida ao estudo do processo de conhecimento, aos encontros com advogados e psicólogos especializados em crimes sexuais, às visitas nas unidades penitenciárias, à venda da creche, à reconfiguração das finanças da família, à mudança de apartamento e etc. Enquanto o tecido relacional afetado pelo processo transformava-se, Helena (re)fazia a si como especialista em nome de Altair. A forma mais material do engajamento amoroso dela é o dossiê que escreveu numa linguagem jurídica e emotiva, produtora da defesa de seu marido e de uma crítica severa às práticas do policial/ psicólogo que assinou os 'falsos' relatórios psicológicos das vítimas. Dentre os inúmeros documentos anexados ao dossiê, está o acórdão do Conselho Regional de Psicologia que aplica a cassação do registro profissional em psicologia desse policial em razão do descumprimento 
do código ético profissional sob julgo. A cassação foi resultado direto da denúncia ético-disciplinar montada pela própria Helena ${ }^{5}$.

Escapa às minhas pretensões a análise minuciosa das mais de cem páginas do dossiê, mas importa dizer que, antes de produzir esse material, Helena se matriculou em um curso de investigação e contratou uma psicóloga/psicanalista para avaliar a qualidade técnica dos laudos produzidos pelo policial. Na ocasião em que estive com essa psicóloga/ psicanalista, ela demonstrou-se contrária à legitimação pelo judiciário de laudos considerados imprecisos e falhos. "Aquilo não deveria nem ser considerado um laudo", disse. Helena angariou a sua volta, investindo quantidade bastante razoável de dinheiro, tempo e afeto, um conjunto de pessoas e relações apto a expandir a força da injustiça e a atrair outras pessoas. Não quero, contudo, transmitir a impressão de que ela podia multiplicar a extensão das relações para todos os lados. Eu a conheci por intermédio de um interlocutor que assistiu reportagens, veiculadas em jornais e canais televisivos, sobre o caso de Altair e me disse que o mesmo policial-psicólogo tinha atuado em seus processos. O interesse dele na incitação à minha aproximação à Helena era claro: conseguir documentos que poderiam operar como provas e expandir assim a força jurídica da narrativa de injustiça. É importante salientar também que Altair, diferente de Pablo, narrou a injustiça sempre via documentos (portanto, falava sobre pessoas que existiam nos autos), não foi assistido pela defensora Fabiana durante a fase de execução penal e já tinha terminado de cumprir pena quando o conheci.

Nem mesmo toda a carga de verdade que Helena conseguiu reunir, após conquistar o descrédito do relatório psicológico, bastou para que a revisão criminal de seu marido fosse julgada procedente pelo time de desembargadores. Quando cheguei a casa dela, poucas horas depois da decisão judicial negativa ter sido comunicada, Helena e Altair estavam devastados. Ela dizia não saber se queria continuar lutando. Ele parecia mais decidido em 'mandar para Brasília'. A pergunta que rondava a todos era a de que adiantava o esforço. Altair, que costumava ficar em silêncio enquanto sua esposa assumia o controle nar- 
rativo da história dos dois, parecia chocar-se com tudo em função da decisão: a corrupção; o 'golpe' ; postagens no facebook; o desembargador 'A' que era uma pessoa perigosa ligada a 'B'; e assim por diante. A decisão judicial fazia Altair afundar-se em uma experiência de contato com um mal generalizado, isto é, disperso em muitos lugares, pessoas e circunstâncias. Ele agia como se o mundo não tivesse jeito. Helena buscava trazê-lo de volta lembrando que a vida deles era confortável. Tinham como viver bem. Uma viagem? - pensei. Mesmo a raiva de Altair parecia contida. Ele seguia falando tão moderadamente quanto falou nas outras ocasiões em que estivemos juntos. Helena, enquanto fumava, acendeu um incenso e agiu com o ar irônico dos que sabem que sabem mais. "Eu te avisei que ia dar nisso; não avisei, Everton?".

Por trás da narrativa de injustiça de Altair e Helena, existiam outras pessoas responsáveis pelo mal: uma sócia gananciosa e mães que expunham seus filhos. Helena e Altair quase não falaram sobre essas mulheres ${ }^{7}$. Elas surgiram tal qual flashes que abruptamente nos alcançam e somem. A temporalidade curta da acusação dirigida às empreendedoras morais e a preferência pela construção prolongada dos erros estatais nos conta sobre o que Helena aprendeu ao longo da sua jornada. Ela sabia o que dizer e o que mobilizar, visando alcançar resultados morais e jurídicos. Helena acionava em sua fala jargões técnicos e, quando notava que eu não os entendia, costumava explicá-los. Os anos investidos - uma década, estimo - na revisão criminal que falhou projetam em direção ao futuro, em um movimento anexado e subordinado à projeção da verdade jurídica, um dossiê inteiro. $\mathrm{O}$ próprio mal substanciado prioritariamente na figura do policial-psicólogo impulsionava o amor como emoção que habilitava o posicionamento moral e, mais do que isso, cristalizava-se em documentos como forma de devoção ao marido em sofrimento. $\mathrm{O}$ dossiê feito para a Justiça, mas pela Justiça invalidado, segue em direção ao futuro enquanto ato ético. Mesmo o 'contralaudo', assinado por uma renomada psicóloga/ psicanalista motivada por um ímpeto político-profissional, pode ser visto como gesto profundo de engajamento entre os dois amantes. 
Acredito que algumas ponderações de Lilah Abu-Lughod (1986) sobre sentimentos velados em uma comunidade beduína no deserto do Egito, ainda que não aplicáveis diretamente ao meu material, podem ser elucidativas. A autora argumenta que a linguagem da poesia é uma forma beduína de expressar a vivência de amores que não podiam ser enunciados em conversas públicas e casuais. $\mathrm{O}$ amor versado em poemas seria um ato de rebelião, uma forma de fazer valer a ideia da escolha do parceiro desejado em uma sociedade onde o parceiro a ser amado é aquele que foi designado por intermédio de um complexo sistema de transações matrimoniais. Lembrando o aspecto político da poesia beduína, o dossiê é uma materialização bem acabada da forma burocrática de exprimir o amor. O dossiê, os laudos e demais documentos são atos amorosos de cunho burocrático, pois relevam um esforço afetivo-político de contestação da legitimidade da Justiça em proferir sentenças condenatórias que perpassam o aprendizado e a mobilização da linguagem jurídica em nome daquele a quem se quer o bem. Esses documentos são políticos também porque instauram narrativas que substancializam a maldade, seja quando atidas aos empreendedores morais que forjaram a acusação de estupro, seja quando focadas em funcionários da administração pública. A política materializada em papéis é fruto de uma maneira de sentir e conduzir a si mesmo enquanto sujeito moral de uma dada ação. Em outras palavras, o amor faculta a tomada de posição moral passível de se racionalizar em conformidade às lógicas administrativas. Tratava-se da busca pela legitimação pela Justiça não exatamente do laço amoroso, sim daqueles papéis que, sendo desde o princípio amor, buscavam produzir efeitos de verdade juridicamente eficazes.

O amor como emoção que habilita a forma burocrática de engajamento continuado com outro, alvo de maldade, comporta ainda uma carga religiosa, se considerarmos que esse sentimento 'anda junto à fé'. Desse ângulo, é possível sugerir uma aproximação entre Roberta e Helena, visto que ambas apontavam para a análise do amor como ato ético (Jabor 2006), espécie de prática virtuosa formadora de relações 
e informada pelo cristianismo. Helena, ainda mais gravemente que Roberta, mesclava a disposição à confiar ao amor. Não estou sugerindo que elas eram pessoas que cultivavam os mesmos vínculos religiosos, apenas sinalizando que o cristianismo é um fenômeno de larga abrangência capaz de informar atos amorosos. A leitura proposta por Jabor (2006) é pertinente aqui menos porque dedicada a uma exegese das noções de ágape e caritas, caras à tradição cristã, e mais porque sustenta a relevância de nos indagarmos sobre o que esse amor traz ao mundo. Dossiês, mas também a busca por carteirinhas de visitação. Indo além, pode-se dizer que compreensão do amor como ato favorece a descrição das disposições para a ação e a observação da possibilidade de tais disposições, ainda que orientadas por moralidades historicamente forjadas, variarem surpreendentemente no cotidiano (Das 2010). Em outras palavras, não é porque a figura do pedófilo está associada de maneira nevrálgica a do monstro que as disposições para a ação serão necessariamente orientadas por essa associação. Coloco em relevo a possibilidade de homens sentenciados por crimes sexuais serem prioritariamente percebidos pelas pessoas que os amam a partir da posição afetivamente marcada que eles ocupam nos laços de parentesco. $\mathrm{O}$ marido acusado de estupro não deixa necessariamente de ser percebido partir da posição relacional que ocupa, e esse laço social torna-se ainda mais crítico quando o amor que lhe embala aparece cruzado ao fenômeno do cristianismo, mais precisamente ao valor atribuído a certa maneira de amar, confiar, ter fé.

Sugiro pensarmos que a proximidade afetiva torna-se chave analiticamente não somente porque através dela podemos perceber o trabalho de formação de uma pessoa em relação a outra, mas também porque através dos minúsculos atos cotidianos podemos descrever a tradução de afetos em linguagens que, a princípio, se querem hostis na nossa cosmologia. Em outro momento, questionando o efeito da separação entre o político e o afetivo, reiterada pelas grandes narrativas sobre o Ocidente (Viveiros de Castro \& Benzaquen 1977), busquei demarcar que perdemos o cotidiano quando apenas seguimos 
reafirmando tais narrativas (Rangel 2018). Partindo uma vez mais da confusão produtiva entre os ditos domínios sociais, privado e público, e entre linguagens, afetiva e racional-legal (Weber 2000), parece possível ver mais facilmente o amor se realizar na forma burocrática em nome de um marido. Refiro-me a gestos afetivos que não abdicavam de se realizarem como documento, ainda que nada impedisse o questionamento da legitimidade do dossiê pela Justiça. A resposta de Helena, em face desse ataque, vinha sendo a da ampliação da racionalização burocrática do gesto de amor em busca de eficácia jurídica. O reconhecimento analítico da prerrogativa do cotidiano no que diz respeito à articulação e desarticulação de 'mundos' - por vezes hostis, por vezes conexos (Zelizer 2005) - é relevante à fomentação da nossa capacidade de perceber como emoções e moralidades caminham junto à burocracia estatal. No caso de Helena e Altair, trazendo à vida papéis que, mesmo após terem sido considerados insuficientes por desembargadores ao sucesso da revisão criminal, seguiam disputando pela sua legitimidade jurídica.

\section{Tempo e gênero}

Conhece-se, finalmente, as razões que me fizeram iniciar este artigo salientando que os homens sentenciados dependiam dos recursos narrativos, das emoções e dos valores sociais constitutivos dos tecidos relacionais em que habitavam para que pudessem existir em alguma extensão do mundo como honestos e/ou trabalhadores. Tratava-se, afinal, de um trabalho ético-moral de produção de humanidade acompanhado pela projeção contínua da sentença condenatória em direção ao futuro. Porque a sucessão dos acontecimentos da vida vivida pelos meus interlocutores carregava o peso do mal articulado em documentos, formas de conter a marcha da verdade jurídica emergiam. Através de práticas específicas de manipulação do estigma (Goffman 1988), Pablo nublou a monstruosidade posicionada sobre a sua face e pôde assim se vincular à Roberta. Falando em máscaras, admito a existência de ações capazes de obliterar o passado marcado pelo crime 
sexual em nome da produção de um cotidiano no interior do qual a ocultação do crime podia imperar. Pode-se até supor que haja quem seja capaz de viver uma vida sujeita à fomentação de estratégias de encobrimento, mas gostaria de acentuar que, quando falo em máscara, estou pensando principalmente na narrativa de injustiça como esforço coletivo de desconstrução da monstruosidade. Entendo que a afirmação da injustiça busca negar a semelhança entre as pessoas produzidas pelos processos de conhecimento (tempo passado) e os homens que pude conhecer durante execução penal (tempo presente). Em outras palavras, assim que os meus(minhas) interlocutores(as) me ouviam dizer que estava realizando uma pesquisa com/sobre homens sentenciados por crimes sexuais e pessoas a eles vinculadas, iniciava-se quase instantaneamente o trabalho de afastamento do estigma, feito de acusações, documentos e/ou desconfianças, capaz de encobrir faces humanas.

No que se refere a Pablo e Altair notei que a destruição causada pela condenação era vivida como 'perda', para além de material, simbólica. Ideias a eles relevantes, como as de bom marido e trabalhador, tinham sido frustradas injustamente. Olhando para as masculinidades, tal como performatizadas, pude entender que a frustração correspondia a uma maneira comum de perceber a passagem do tempo, após a condenação. Desse evento crítico emanou uma quebra temporal. Ao passo em que sentença condenatória inaugurou uma vida marcada pelo desejo de retirar de si a máscara do pedófilo, bem como pela presença da figura do pedófilo como um fantasma, nasceu um passado em que a verdade jurídica não existia, um momento no tempo em que as relações e as idealizações de si não estavam afetadas pelo mal. O sentimento de frustração enunciava-se nas experiências masculinas por intermédio do contraste entre a percepção de como a vida era e de como passou a ser. Parecia haver algo incômodo no que dizia respeito ao presente que não era brilhante como o passado em que Altair administrava uma creche e Pablo era um servidor público. O próprio brilho do passado derivava da abrupta capacidade da con- 
denação de criar em retrospecto o tempo em que os meus interlocutores levavam uma vida que lhes parecia digna. Essa valorização do que foi em certo sentido perdido só existe em contraste com o presente que a todo instante faz lembrar que o futuro não será tal qual uma vez imaginado. Talvez a melhor forma de caracterizar a frustração seja aproximando-a à lembrança das promessas de um passado e à ideia de um futuro injustamente roubado. A quebra temporal entre esse passado abrilhantado e esse futuro que não será cria o intervalo de onde emanam discursos de injustiça coloridos pela frustração.

A minha aposta, contudo, é a de que não devemos congelar a sensação comum de que algo foi perdido em uma única relação entre o sujeito e a frustração, pois os ideais frustrados de Pablo e Altair, ainda que semelhantes, não culminam em modos de sentir e agir idênticos. As respostas à frustração não são as mesmas, nem mesmo a frustração é a única resposta emocional possível à condenação. Espero ter demonstrado que o silêncio importava a Altair e a mentira a Pablo, mas também que esses atos e sentimentos qualificavam condutas masculinas, que, sempre de modo singular, manejavam a experiência da condenação como quebra temporal. Devo demarcar ainda que os meus apontamentos sobre a relação entre certos homens e a frustração são limitados a ponto de não ser possível afirmar qual é o impactado real desse sentimento na vida das pessoas. Tenho a impressão de que, embora seja viável argumentar que alguns dos meus interlocutores faziam-me perceber o sentimento de frustração nas bordas do discurso de injustiça, não tenho como aferir o vigor desse sentimento e nem mesmo o seu espraiar ou não pela vida cotidiana. Como já sugerido, é mais acertado fazer ver que a frustração se insinuava nos atos de fala qualificando uma relação com o tempo. Mais precisamente, a quebra temporal quando associada ao gênero resultava em condutas que, frente a mim, criavam provedores (Pablo) e faziam a importância do silêncio (Altair) associada à injustiça contada no feminino (Helena).

Sabendo que os meus dados são também limitados quanto à relação entre as experiências masculinas de frustração e os atos de amor, 
posso apenas entrever, a partir da relação entre Helena e Altair, um modo de correlacionar masculinidade e feminilidade. Helena era quem mais fazia com que a máscara do pedófilo fosse distanciada e quem mais multiplicava a extensão e a densidade do tecido relacional em que Altair existia como homem honesto. Quando ela se engajava na injustiça, via produção de papéis contestatórios, tornava-se evidente a qualidade imprescindível do trabalho ao qual se dedicava. Tratava-se da capacidade de fazer do amor não somente um mergulho no passado, mas também uma maneira de habitar o presente transformando a disposição em confiar no Altair há muito conhecido em uma forma burocrática apta a disputar a sua própria legitimidade como documento. Desse ângulo, talvez seja mais apropriado pensar a quebra temporal como um passado distante, fonte do conhecimento sensível e verdadeiro sobre o marido a ser amado em atos, e um passado recente, marcado pelo germinar da narrativa de injustiça como efeito da condenação. A injustiça dependia do passado distante, propriamente da capacidade de Helena manter o que aprendeu sobre Altair em momento anterior à condenação como uma temporalidade quente no presente. $\mathrm{Na}$ medida em que ela foi se transformando em investigadora, a confiança que a permitia reencontrar continuamente nele o homem amado foi nutrida, dia após dia, através do próprio engajamento, pouco a pouco, materializado em dossiê. Manter o passado distante quente no presente era o mesmo que seguir em direção ao futuro em um estado de retorno afetivamente orientado.

Os atos de amor que fazem a injustiça relevam ainda um trabalho bastante próximo das práticas de cuidado, considerando, por exemplo, que o cuidado muitas vezes designa gestos a partir dos quais eventos críticos são absorvidos e sofrimentos aliviados. Se manter quente a 'fé' em Altair implicou que Helena convertesse parte expressiva do 'tempo para si' em 'tempo dedicado ao outro' (Fernandes 2018), notase que o amor devoto realiza-se através de um trabalho hercúleo, difícil de ser integralmente agradável a quem o efetua. Perguntando-me sobre o que fazia Helena exibir tamanho engajamento e encontrando 
em campo o amor que não se alegra com a injustiça como resposta, terminei concluindo o mesmo que parte da literatura especializada: o cuidado é idealizado pelos sujeitos como prática ética a tal ponto que aquele(a) que se esforça pelo outro reconhece nos seus atos de devoção o seu próprio valor moral (Caduff 2019). Nesse sentido, cabe observar que a devoção habilita um discurso de autoridade feminino sobre a vida à dois estremecida pela condenação por estupro de vulnerável. $\mathrm{O}$ exercício de algum poder narrativo recompensava Helena, dava-lhe algum prazer. Ainda segundo Carlo Caduff, menos usuais seriam as perguntas direcionadas a quem recebe o cuidado não somente porque os autores de etnografias compartilhariam com os(as) cuidadores(as) sobre os quais escrevem a mesma ênfase no cuidado enquanto 'socialidade exemplar' (ambos agiriam como se cuidado precisasse ser cuidado), mas também porque aquilo que dizem aqueles que são cuidados poderia ser socialmente ácido ou simplesmente ameaçar as idealizações morais manifestas por um autor ou outro.

Os dados que reuni sobre Helena e Altair apontam justamente no sentido da 'inflação ética do cuidado' que Caduff questiona. É certo pensar que a minha interlocutora fundia o trabalho que executava em nome do seu marido a uma imagem moral do bem fazer. É nesse ponto, entretanto, que acredito ser necessário desacelerar. Executando um trabalho usualmente pensado como feminino, Helena podia até querer fazer vivo o passado distante, trazendo para perto de si o marido que há muito conhecia, mas o Altair de quem ela cuidava no presente era um Altair assombrado por fantasmas. A quebra temporal que o amor buscava contornar, apelando à reconstrução da linearidade entre a vida anterior e posterior ao processo, não podia ser de todo resolvida. Levanto a possibilidade das tentativas de recuperação dos mais variados ideais de homem (pai, trabalhador, marido e etc.) serem inseparáveis da ameaça de desumanização exercida pela figura do pedófilo, de tal forma que, mesmo a masculinidade feliz em calar-se para assim ser protegida pela feminilidade capaz de ocupar magistralmente a posição de fala, termina sujeita à impossibilidade do trabalho de 
cuidar a tudo solucionar. Foi mais fácil perceber o amor devoto de Helena realizar-se como discurso de autoridade sobre feitos, acontecimentos e relações do que perceber a cicatrização plena de Altair em um contexto caracterizado pela força cortante e contínua do estigma .

\section{A importância do mal}

Venho argumentando que a narrativa de injustiça requer, costumeiramente, que os empreendedores morais responsáveis pela acusação de estupro sejam convertidos em pessoas más que, ao acionarem a administração estatal alegando a proteção de crianças e adolescentes, buscam a afirmação de alguma demanda espúria. $\mathrm{O}$ mal que se torna visível no ato injusto de acusar é produzido como uma qualidade substantiva, a essência de pessoas como a mãe de Marlene, e vivido como excesso fabricado pela administração incorreta de justiça. Seguindo essa linha de raciocínio, a Justiça em maiúsculo sobre a qual falam os meus interlocutores pode ser descrita como uma engrenagem moral que, devido a sua capacidade de instaurar cartas de sentença condenatórias, projeta sobre os tecidos relacionais prejuizos que ultrapassam em muito a competência de um empreendedor moral em produzir uma realidade: um estuprador, um pedófilo, um abusador. Estar sujeito à operação moral da Justiça é perceber o Estado

"[...] como entidade que tem concretude não apenas em suas formas institucionais, em sua dimensão de administração e governamentalidade, mas como entidade simbólica que atravessa e ordena o cotidiano das pessoas: aquele que faz; que deve fazer; que pode realizar ou escolher não realizar" (Vianna \& Farias 2011:93).

A carnatura da Justiça como ente está correlacionada à fase de conhecimento: produção de provas, oitivas, sentenças. Pode-se dizer que são as práticas persecutórias que terminam ampliando o mal, do ponto de vista dos meus interlocutores. O corpo dessas práticas se faz visível no policial/psicólogo, que, tal como a Justiça, ouve somente aquilo que dizem os empreendedores morais ou as crianças classificadas como vítimas em documentos. A defesa das crianças e a vontade 
dos punição dos juízes eram costumeiramente costuradas visando descrever tanto a força desproporcional das práticas estatais engajadas na acusação quanto a sensação, derivada dessa desproporcionalidade, de que ninguém queria escutar aqueles que foram acusados de estuprar. Nesse sentido, o sofrimento que experimentam os sentenciados foi causado por práticas de administração de justiça moralmente orientadas, isto é, focadas em vítimas que foram tratadas como autoevidentes, e não como 'supostas'. Não é difícil entrever que, quando os meus(minhas) interlocutores(as) acusavam a Justiça de ser uma engrenagem moral, eles(as) estavam dizendo que, se um agente policial podia ser uma metonímia do Estado, esse último, tal qual o primeiro, manifestava intencionalidade capaz de produzir lados: crianças e mulheres como figuras a serem protegidas versus homens como suspeitos, quando não culpados.

Ainda que tenha enfatizado a figura do policial/psicólogo como o grande articulador do infortúnio vivido por Altair e Helena, vale lembrar que, durante de trabalho de campo, o mal era reiteradamente narrado em menção a mulheres que queriam dinheiro, que não suportavam uma separação, que sentiam muito ciúme, que queriam os filhos para si, que faziam macumba, e etc. Mesmo quando os homens apareciam arquitetando maldades, havia mulheres por trás da ação deles. É o caso das mães da creche que Helena possuía. São os repertórios de gênero normativos que fazem confluir com frequência maior o acionamento da moralidade do mal em alusão ao feminino, deixando em segundo plano a substancialização do mal em masculinidades. São também esses repertórios que fazem o cuidado apresentar-se usualmente como feminino.

Acredito que, estando claro que o mal somente pode produzir efeitos deletérios quando atuado e administrado, a sua substancialização não deve ser perdida de vista por uma razão específica: o mal substantivo é uma explicação possível para o porquê de alguém ser capaz de causar danos profundos em nome de interesses mesquinhos. $\mathrm{Na}$ medida em que o sofrimento experimentado por homens sen- 
tenciados é vivido como excessivo, o mal emerge como essência de pessoas que, pouco preocupadas com a dor do outro, engajam-se em campanhas acusatórias engrandecidas pela força desproporcional da Justiça. A fé no mal como substância entranhada estava espraiada e, por isso, podia atualizar-se em atos de fala ou em substancializações discursivo-morais. Evans-Pritchard (2005) propôs que a bruxaria entre os Azande é uma razão suficiente, um esquema de explicação dos infortúnios completamente cabível. A narrativa de Pablo era a que mais se aproximava do mal como princípio de causalidade totalizante. Helena e Altair privilegiavam os 'erros da Justiça'. Agiam como se a dimensão moral e emotiva dos seus discursos devesse ser proferida em tom menor, isto é, devesse ser articulada com a racionalidade burocrática. Diferente da bruxaria entre os Azande, o mal como regime de explicação dos infortúnios em nossa sociedade está sujeito a uma circulação em que a sua própria legitimidade explicativa é contestável.

Cabe tornar a Zelizer (2005) para lembrarmos que os mundos hostis são tão nossos quanto os mundos conexos. Quando priorizavam e idealizavam a linguagem burocrática, os meus(minhas) interlocutores(as) estavam produzindo esferas distintas (moral-afetivo/ racional-legal) e atribuindo à linguagem que priorizavam maior capacidade de produção de verdade. Ninguém carregava documentos à toa e nem batizava atos de amor como dossiê sem razão. Helena, aproximando o amor à fé cristã, revelava a fé com a qual se rendia aos documentos. Se, por um lado, o amor que confia na injustiça está enlaçado a uma confiança quase religiosa na burocracia, por outro, a separação entre esferas era demandada cada vez que um purismo de cunho racional -legal - refiro-me à desqualificação do dossiê como exclusivamente afeto, não sendo prova ou documento legítimo - se apresentava e a narrativa injustiça era rechaçada como mero discurso moral. Nesse horizonte, o mal não podia ser um 'princípio' de explicação totalizante, ainda que Pablos despontassem, aqui e ali, abdicando do privilégio da verdade jurídica. Espero ter demonstrando que a substancialização do mal, traduzida ou não a uma linguagem burocrática, era dispo- 
sição ético-moral cultivada pelos que perderam, mas queriam ainda 'vencer' em algum registro da vida. A relevância da preocupação com substancialização do mal reside justamente na possibilidade de compreender os meandros ético-morais das relações de poder que cruzavam tecidos relacionais afetados pela condenação de homens amados, homens cuja humanidade estava em disputa. Desse ângulo, percebe-se que o mal era significativo à conformação do comportamento que os(as) meus(minhas) interlocutores(as) refletiam como o apropriado e/ou atuavam como disposição cultivada. Se retirados de cena o mal substancializado e os papéis feitos com amor, restariam apenas as faces encobertas pelo estigma não combatido pelos sofreram a injustiça e pelos que nela creram.

\section{Notas:}

1 Este artigo, parte da minha tese de doutorado em fase de escrita, é fruto do trabalho de campo realizado entre 2015 e 2018 junto a homens sentenciados por crimes sexuais, pessoas afetivamente vinculadas a eles e uma defensora pública. Nesse período, transitei entre presídios, manicômios judiciários, casas/relações de interlocutores(as) e pelo Núcleo do Sistema Penitenciário da Defensoria Pública do Rio de Janeiro (Nuspen-RJ).

2 Segundo a autora, "morality requires emotion because affects provides the motivation for taking particular moral positions towards events" (Lutz 1998:76-77).

3 Refletindo sobre a emergência do conceito de gênero e o seu impacto político e teórico, Piscetelli argumenta que, durante certo tempo, "em termos teóricos, elas [feministas] trabalharam com uma idéia global e unitária de poder, o patriarcado, numa perspectiva na qual cada relacionamento homem/mulher deveria ser visto como uma relação política. [...] O conceito foi importante na medida em que distinguia forças específicas na manutenção do sexismo e útil, em termos da tentativa feminista de mostrar que a subordinação feminina, longe de ser inevitável, era a naturalização de um fenômeno contingente e histórico, era que se o patriarcado teve um início poderia ter um fim. [...] O problema é que a utilização desse termo fora do seu contexto obscurecia a compreensão das relações sociais que organizam diversas formas de discriminação" (Piscitelli 2002:6-7). Reitero aqui o argumento da autora e o seu complemento: "O que me interessa reter de tudo isto é que o conceito de gênero começou a ser desenvolvido como uma alternativa ante o trabalho com o patriarcado A elaboração desse conceito está associada à percepção da necessidade de associar essa preocupação política a uma melhor compreensão da maneira como o gênero opera em todas as sociedades, o que exige pensar de maneira mais comple- 
xa o poder. Vemos, assim, que as perspectivas feministas que iniciaram o trabalho com gênero mantêm um interesse fundamental na situação da mulher, embora não limitem suas análises ao estudo das mulheres" (Piscitelli 2002:11).

4 A conceituação do gênero enquanto performatividade está emaranhada às relações de poder no sentido foucaultiano do termo. Se, por um lado, a prescrição e reiteração de comportamentos e falas fundados em uma matriz heterossexual conformam diariamente as verdades do gênero e sedimentam a sua performatividade, por outro, a necessidade de repetição destes mesmos atos indica que sucesso completo das citações normativas nunca é alcançado, pois a coerência e a estabilidade das mesmas estão sempre ameaçadas pela impossibilidade de realização plena dos ideais de feminilidade e masculinidade. Neste sentido, a performatividade pode ser compreendida como um processo que, em sua capacidade produtiva, também conforma e habilita repetições subversivas.

5 Ainda que Helena não tenha denunciado apenas um único policial-psicólogo, acredito que compreensão da dedicação dela ao seu marido não é drasticamente afetada pelos limites da minha possibilidade de descrever múltiplas ações técnicomorais.

6 Refiro-me a uma forma de enquadramento dos acontecimentos que redundaram no impeachment da presidenta Dilma Rousseff.

7 Os homens, pais dessas crianças, foram ainda menos mencionados.

\section{Referências:}

ABU-LUGHOD, Lilah. 1986. Veiled Sentiments: Honor and Poetry in a Bedouin Society. Oakland: University of California Press.

ANDRADE, Fabiana. 2018. Mas vou até o fim: narrativas femininas sobre experiências de amor, sofrimento e dor em relacionamentos violentos e destrutivos. Tese de Doutorado. São Paulo: USP.

LUTZ, Catherine. 1998. Unnatural Emotions: everyday sentiments on a Micronesian Atoll and their challenge to western theory. Chicago: University of Chicago Press.

AUSTIN, John. 1962. How to Do Things with Words. Cambridge, Mass.: Havard University Press.

BUTLER, Judith. 2006. Gender Trouble. Feminism and the Subversion of Identity. New York: Routledge.

CADUFF, Carlo. 2019. "Hot Chocolate". Critical Inquiry, 45(3):787-803.

CAREY, Matthew. 2017. Mistrust: an ethinographic theory. Chicago: Hau Books by Chicago Press.

DAS, Venna. 2010. "Engaging the life of the other: love and everyday life". In LAMBEK, Michael (ed.): Ordinary ethics. Anthropology, language and action, pp. 376-399. New York: Fordham University Press. 
DAS, Venna. 2012. "Entre palavras e vidas: um pensamento de encontro com margens, violências e sofrimentos: entrevista com Veena Das”. Dilemas: Revista de Estudos de Conflito e Controle Social, 5(2):335-356.

EVANS-PRITCHARD, E. 2005. Bruxaria, Magia e Oráculos entre os Azandes. Rio de Janeiro: Zahar.

FERNANDES, Camila. 2018. Figuras da causação: sexualidade feminina, reprodução e acusações no discurso popular e nas políticas de Estado. Tese de Doutorado. Rio de Janeiro: UFRJ/MN/PPGAS.

. 2018. "O tempo do cuidado: batalhas femininas por autonomia e mobilidade”. In RANGEL, E., FERNANDES, C. \& LIMA, F. (eds): (Des) Prazer da norma, pp. 297-320. Rio de Janeiro: Papéis Selvagens.

FOUCALT, Michael. 2006. Ditos e Escritos V. Rio de Janeiro: Forense universitária.

. 1998. História da Sexualidade 2. O uso dos prazeres. Rio de Janeiro: Graal.

GOFFMAN, Erving. 2012. Estigma: notas sobre a manipulação da identidade deteriorada. Rio de Janeiro: Zahar.

JABOR, Juliana. 2006. "A prática do amor e o amor prático: identidade e sentimentos em uma família religiosa de classe média”. In DUARTE, L. F. D. et al (eds): Família e Religião, pp. 169-189. Rio de Janeiro: Contra Capa.

LAMBEK, Michael. 2015. "Lecture 1: Living as if it mattered". In LAMBEK, Michael et al (ed.): Four Lectures on Ethics: anthropological perspectives, n.p. Chicago: Hau Books by Chicago Press.

LOWENKRON, Laura. 2015. O Monstro Contemporâneo: a construção social da pedofilia em múltiplos planos. Rio de Janeiro: EdUERJ.

LUTZ, C. 1988. Unnatural Emotions: everyday sentiments on a Micronesian Atoll and their challenge to western theory. Chicago: The University of Chicago Press.

MACHADO, Lia Z. 1998. "Masculinidade, sexualidade e estupro: as construções da virilidade”. Cadernos Pagu, 11:231-27.

MAYA, Mayblin. 2019 “The Anarchic Institution”. AOCT Press. (http://aotcpress. com/articles/anarchic-institution/; Acesso em 21/05/2019).

PISCITELLI, A. 2002. "Gênero: a história de um conceito". In ALMEIDA, H. B. \& SZWAKO, J. E. (eds): Diferenças, Igualdade. São Paulo: Berlendis \& Vertecchia.

RANGEL, Everton. "Amores Censurados: sobre gritos, olhares, tapas e fissuras". In RANGEL, E., FERNANDES, C. \& LIMA, F. (eds): (Des)Prazer da Norma, pp. 367-385. Rio de Janeiro: Papéis Selvagens.

VIANNA, A. \& FARIAS, J. 2011. "A Guerra das Mães: dor e política em situações de violência institucional”. Cadernos Pagu, 37:79-116.

VIVEIROS DE CASTRO, E. \& BENZAQUEM DE ARAÚJO, R. 1977. "Romeu e Julieta e a origem do Estado”. In VELHO, Gilberto (ed.): Arte e sociedade: ensaios de sociologia da arte, pp.130-169. Rio de Janeiro: Zahar,. 
WEBER, MAX. 2000. Economia e Sociedade: fundamentos da sociologia compreensiva. Brasília: Editora Universidade de Brasília.

ZELIZER, Viviana. 2011. A Negociação da Intimidade. Petrópolis:Vozes.

\begin{abstract}
In this article, result of an ethnography that was done with men 'convict' as 'child molesters' and with people affectively linked them, I will describe the effects of 'sentences' on dense relations, paying special attention to the problem of evil, which is the cause of much suffering, and to the forms of engagement that pass through the practice of love towards one another. The work, at once affective, bureaucratic, moral and narrative, to which my interlocutors devote themselves, suggests the necessity of the production of relationships in which 'condemned' men can inhabit as victim of injustice loved in acts by those who fight against the substance of evil. I suggest that we must understand this work as an ethical relational activity. After all, i seek to describe a series of links between emotions, morality, state and gender.
\end{abstract}

Keywords: Rape, Love, Morality, Evil, State.

Recebido em Abril de 2019.

Aprovado em Julho de 2019. 